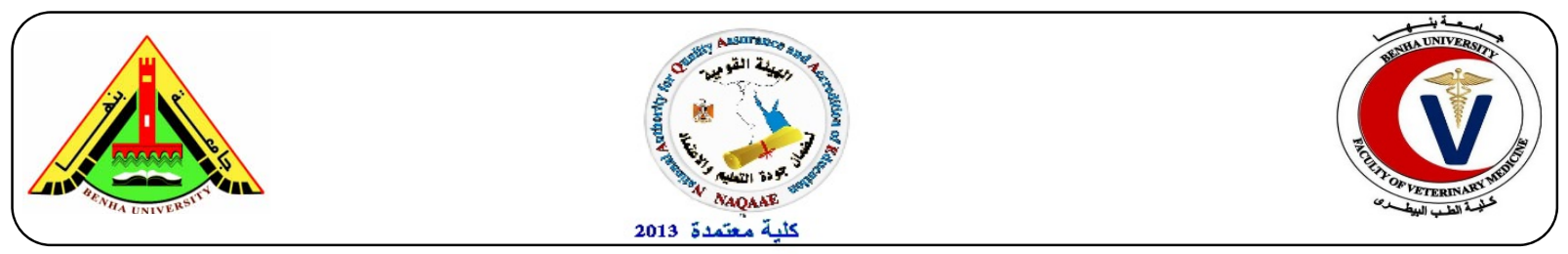

\title{
Estimation of some biogenic amines on chicken meat products
}

\author{
Hemmat, M. Ibrahim1; Reham, A. Amin'; Nesreen, Z. Eleiwa² and Noha, M. Ahmed \\ ${ }^{1}$ Food Control Dept., Faculty of Veterinary Medicine, Benha University. \\ ${ }^{2}$ Food Hygiene Dept., Animal Health Research Institute, Tanta Branch.
}

\section{A B S T R A C T}

Sixty random samples of raw thigh \& breast, half cooked chicken shawerma \& shiesh tawook, fully cooked chicken shawerma and fully cooked chicken shiesh tawook (10 of each) were collected from different markets in Gharbia governorates and analyzed for biogenic amines by HPLC. The obtained results indicated that the mean values of histamine, cadaverine and putrescine $(\mathrm{mg} / 100 \mathrm{~g})$ were $10.88 \pm 0.91,12.65 \pm 1.10$ and $4.54 \pm 0.32$ for raw thigh, $4.54 \pm$ $0.32,9.86 \pm 0.87$ and $9.86 \pm 0.87$ for raw breast $16.56 \pm 1.24,19.81 \pm 1.52$, and $11.41 \pm 0.96$ for half cooked shawerma, $12.29 \pm 0.97,16.20 \pm 1.08$ and $9.98 \pm 1.08$ for half cooked shiesh tawook, $12.93 \pm 1.03,16.69 \pm 1.33$ and $8.01 \pm 0.63$ for fully cooked shawerma and $11.68 \pm 0.97,11.91 \pm 0.97$ and $7.47 \pm 0.50$ respectively for fully cooked shiesh tawook. According to the permissible limits recommended by EOS (2005) 10\%, 30\%, 20\%, 20\% and 20\% of the examined samples of raw thigh, half cooked shawerma, half cooked shiesh tawook, fully cooked shawerma and fully cooked shiesh tawook were unaccepted. All raw breast samples were accepted as a result of their histamine content. While, 20\%, 40\%, $30 \%, 30 \%$ and $20 \%$ of the examined samples raw thigh, half cooked shawerma, half cooked shiesh tawook, fully cooked shawerma and fully cooked shiesh tawook were unaccepted. Moreover, raw breast samples were accepted as result of their cadaverine content respectively. Accurately $10 \%$ of half cooked shawerma were unaccepted while all examined samples were accepted as a result of putrescine content.

Key words: Biogenic amines, chicken meat products, histamine, cadaverine, putrescine.

(http://www.bvmj.bu.edu.eg)

(BVMJ-32(1): 23 -28, 2017)

\section{INTRODUCTION}

The worldwide poultry meat production and consumption have increased rapidly and consumption of poultry meat in many parts of the world will continue to grow. Competitive price, the absence of cultural and religious obstacles, and dietary and nutritional properties are the main factors explaining the poultry meat's attractiveness for consumers (Petracci and Cavani, 2012). The production and consumption of ready to eat chicken meat products have increased significantly throughout the world during the last decade, due to their desirable sensory characteristics, easiness and variety of preparation methods (Balamatsia et al., 2006). Biogenic amines in food are formed as a result of the growth of decarboxylase-positive microorganisms under conditions propitious for that enzyme activity (Halasz et al., 1994). Histamine poisoning is a chemical intoxication of short incubation period (30 minutes to 1 hour). It is often manifested by a wide variety of symptoms as urticaria, edema, localized inflammation and rash (Jean et al., 2001). Temperature dependent changes took place in the concentrations of putrescine and cadaverine. The changes in the concentrations of these amines were related to the microbiological quality of broiler chicken cuts (Rokka et al., 2003). Putrescine is essential for the growth and function of normal cells. Due to- its electrostatic and covalent interactions with various macromolecules, it fulfils an array of important physiological roles. Its participation in human cell growth and proliferation has been of great interest for its role in tumor growth (Kozova et al., 2009; Krausova et al., 2006).

Therefore, the main goal of the present work was carried out to estimate the biogenic amines as quality index in chicken meat products.

\section{MATERIAL AND METHOD}

\subsection{Determination of biogenic amines by using HPLC:}

Three biogenic amines including histamine, cadaverine and putrescine were determined in all examined samples according to the protocol 
recommended by Krause et al. (1995) and Pinho et al. (2001).

\subsection{Extraction of samples:}

Twenty-five grams of each sample was blended with $125 \mathrm{ml}$ of $5 \%$ Tri chloro acetic acid (TCA) for 3 min using a warning blender then filtration was achieved using filter paper (Whatman No1.) Then, $10 \mathrm{ml}$ of the filtrate were transferred into a suitable glass tube with $4 \mathrm{~g} \mathrm{NaCl}$ and $1 \mathrm{ml}$ of $50 \% \mathrm{NaOH}$. The filtrate was extracted three times ( 2 min each) by using $5 \mathrm{ml} \mathrm{n}$-butanol: chloroform $(1: 1 \mathrm{v} / \mathrm{v})$ and the upper clear layer was transferred to $100 \mathrm{ml}$ separating funnel by using disposable Pasteur pipette. To combine the organic extracts (upper layer), $15 \mathrm{ml}$ of $\mathrm{n}$-heptane was added in separating funnel and extracted three times with $1.0 \mathrm{ml}$ portions of $0.2 \mathrm{~N} \mathrm{HCl}$, the $\mathrm{HCl}$ layer was collected in a glass Stoppered tube. Solution was evaporated just to dryness using water bath at $95^{\circ} \mathrm{C}$ with aid of a gentle current of air.

\subsection{Formation of dansylamines:}

One hundred $\mu 1$ of each stock standard solution (or sample extract) were transferred to $50 \mathrm{ml}$ vial and dried under vacuum. About $0.5 \mathrm{ml}$ of saturated $\mathrm{NaHCO}_{3}$ solution was added to the residue of the sample extract (or the standard). Vial was stoppered and carefully mixed to prevent loss due to spattering. Carefully, $1.0 \mathrm{ml}$ dansyl chloride solution was added and mixed thoroughly using vortex mixer. The reaction mixture was incubated at $55^{\circ} \mathrm{C}$ for $45 \mathrm{~min}$. About $10 \mathrm{ml}$ of distilled water were added to the reaction mixture. Then vial was stoppered and shaked vigorously using vortex mixer. The extraction of dansylated biogenic amines was carried out using $5 \mathrm{ml}$ of diethyl ether for 3 times again vial was stoppered, shaked for 11 min and the ether layers were collected in a culture tube using disposable Pasteur pipette. The combined ether extracts were carefully evaporated at $35^{\circ} \mathrm{C}$ in dry bath with aid of air current. The obtained dry material was dissolved in $1 \mathrm{ml}$ methanol and $10 \mu \mathrm{l}$ was injected in HPLC.

\subsection{Statistical analysis}

The obtained results were statistically evaluated by application of Analysis of Variance (T-TEST) test according to Feldman et al. (2003).

\section{RESULTS}

It is evident from the results recorded in table (1) that the mean values of the histamine levels in the examined samples were $10.88 \pm 0.91^{+} \mathrm{mg} \%$ for raw thigh chicken meat, $8.17 \pm 0.53 \mathrm{mg} \%$ for raw breast chicken meat, $16.56 \pm 1.24 \mathrm{mg} \%$ for half cooked chicken shawerma, $12.29 \pm 0.97 \mathrm{mg} \%$ for half cooked chicken shiesh tawook, $12.93 \pm 1.03$ $\mathrm{mg} \%$ for fully cooked chicken shawerma and $11.68 \pm 0.97 \mathrm{mg} \%$ for fully cooked chicken shiesh tawook.

Table (2) indicated that all examined samples of raw chicken breast were accepted based on their contents of histamine and come in accordance with EOS (2005) which stipulated that the maximum permissible limit of histamine in chicken meat products should not exceed $20 \mathrm{mg} \%$. In contrast, $10 \%, 30 \%, 20 \%, 20 \%$ and $20 \%$ examined samples of raw thigh meat, half cooked shawerma, half cooked sheish tawook, fully cooked shawerma and fully cooked sheish tawook respectively exceeded such permissible limit.

Table (3) declared that the mean values of cadaverine levels were $12.65 \pm 1.10 \mathrm{mg} \%$ for raw thigh, $9.86 \pm 0.87 \mathrm{mg} \%$ for raw breast, $19.81 \pm$ $1.52^{+} \mathrm{mg} \%$ for half cooked shawerma, $16.20 \pm 1.08$ $\mathrm{mg} \%$ for half cooked sheish tawook, $16.69 \pm 1.33$ $\mathrm{mg} \%$ for fully cooked shawerma and $11.91 \pm 0.97$ $\mathrm{mg} \%$ for fully cooked sheish tawook. Table (4) demonstrated that the acceptability of cadaverine levels in the examined samples of raw and heat treated chicken meat products. All raw breast chicken meat was accepted while $20 \%, 40 \%, 30 \%$, $30 \%$ and $20 \%$ of examined samples of raw thigh chicken meat, half cooked chicken shawerma, half cooked shiesh tawook, fully cooked chicken shawerma and fully cooked sheish tawook were unaccepted, respectively, based on their contents of cadaverine according to EOS (2005).

Table (5) revealed that the mean values of putrescine in the examined samples were $4.54 \pm$ $0.32 \mathrm{mg} \%$ for raw thigh chicken meat, $4.15 \pm 0.25$ $\mathrm{mg} \%$ for raw breast chicken meat, $11.41 \pm 0.96$ $\mathrm{mg} \%$ for half cooked shawerma, $9.98 \pm 1.08 \mathrm{mg} \%$ for half cooked sheish tawook, $8.01 \pm 0.63 \mathrm{mg} \%$ for fully cooked shawerma and $7.47 \pm 0.50 \mathrm{mg} \%$ for fully cooked sheish tawook. Table (6) demonstrated that the acceptability of putrescine levels in the examined samples of raw and heat treated chicken meat products. $10 \%$ of the examined samples of half cooked shawerma were unfit for human consumption, while all examined samples were accepted according to Egyptian Organization for Standardization "EOS" (2005). 
Table (1): results of histamine levels ( $\mathrm{mg} \%)$ in the examined samples of chicken meat products $(\mathrm{n}=10)$.

\begin{tabular}{|c|c|c|c|c|c|}
\hline \multirow[b]{2}{*}{ Chicken meat } & \multicolumn{2}{|c|}{ Positive samples } & \multirow[b]{2}{*}{ Min } & \multirow[b]{2}{*}{$\operatorname{Max}$} & \multirow[b]{2}{*}{ Mean \pm S.E. ${ }^{*}$} \\
\hline & No. & $\%$ & & & \\
\hline Raw thigh & 8 & 80 & 1.7 & 22.4 & $10.88 \pm 0.91^{+}$ \\
\hline Raw breast & 8 & 80 & 1.3 & 15.5 & $8.17 \pm 0.53$ \\
\hline Half cooked shawerma & 10 & 100 & 2.7 & 32.5 & $16.56 \pm 1.24^{+}$ \\
\hline Half cooked shiesh tawook & 10 & 100 & 2.1 & 26.9 & $12.29 \pm 0.97$ \\
\hline Fully cooked shawerma & 10 & 100 & 2.5 & 28.2 & $12.93 \pm 1.03^{\mathrm{NS}}$ \\
\hline Fully cooked shiesh tawook & 10 & 100 & 1.8 & 23.2 & $11.68 \pm 0.97$ \\
\hline
\end{tabular}

S.E. ${ }^{*}=$ standard error of mean. + Application of t-test indicated significant differences $(P<0.05)$ between (thigh $\&$ breast) and half cooked (shawerma $\&$ shiesh tawook). NS= Non-significant differences $(P<0.05)$ between full cooked (shawerma \&shiesh tawook)

Table (2): Acceptability of the examined samples of raw and heat treated chicken meat products based on their levels of histamine $(\mathrm{n}=10)$.

\begin{tabular}{|c|c|c|c|c|c|}
\hline \multirow{2}{*}{ Chicken Products } & \multirow{2}{*}{$\begin{array}{c}\text { MRL } \\
(\mathrm{mg} \%)^{*}\end{array}$} & \multicolumn{2}{|c|}{ Accepted samples } & \multicolumn{2}{|c|}{ Unaccepted samples } \\
\hline & & No. & $\%$ & No. & $\%$ \\
\hline \multicolumn{6}{|l|}{ Raw chicken meat: } \\
\hline Thigh & 20 & 9 & 90 & 1 & 10 \\
\hline Breast & & 10 & 100 & 0 & 0 \\
\hline \multicolumn{6}{|l|}{ Half cooked product: } \\
\hline Shawerma & 20 & 7 & 70 & 3 & 30 \\
\hline Shiesh Tawook & 20 & 8 & 80 & 2 & 20 \\
\hline \multicolumn{6}{|l|}{ Full cooked product: } \\
\hline Shawerma & 0 & 8 & 80 & 2 & 20 \\
\hline Shiesh Tawook & 20 & 8 & 80 & 2 & 20 \\
\hline
\end{tabular}

Table (3): results of cadaverine levels ( $\mathrm{mg} \%)$ in the examined samples of chicken meat products $(\mathrm{n}=10)$.

\begin{tabular}{lllllc}
\hline & \multicolumn{3}{l}{ Positive samples } & & \\
Chicken meat & No. & $\%$ & Min & Max & Mean \pm S.E \\
\hline Raw thigh & 10 & 100 & 1.9 & 23.7 & $12.65 \pm 1.10^{+}$ \\
Raw breast & 10 & 100 & 1.4 & 18.2 & $9.86 \pm 0.87$ \\
Half cooked Shawerma & 10 & 100 & 4.0 & 39.6 & $19.81 \pm 1.52^{+}$ \\
Half cooked Shiesh Tawook & 10 & 100 & 2.8 & 31.5 & $16.20 \pm 1.08$ \\
Fully cooked Shawerma & 10 & 100 & 2.9 & 33.1 & $16.69 \pm 1.33^{+}$ \\
Fully cooked Shiesh Tawook & 10 & 100 & 2.2 & 27.9 & $11.91 \pm 0.97$ \\
\hline \multicolumn{4}{c}{+ Application of t-test indicated significant differences $(P<0.05)$ between products }
\end{tabular}

Table (4): Acceptability of the examined samples of raw and heat treated chicken meat products based on their levels of cadaverine

\begin{tabular}{lccccc}
\hline & MRL & \multicolumn{2}{c}{ Accepted samples } & \multicolumn{2}{c}{ Unaccepted samples } \\
Chicken Products & $(\mathrm{mg} \%)^{*}$ & No. & $\%$ & No. & $\%$ \\
\hline Raw chicken meat: & 20 & 8 & 80 & 2 & 20 \\
$\quad$ Thigh & & 10 & 100 & 0 & 0 \\
$\quad$ Breast & & & & & \\
Half cooked product: & & 6 & 60 & 4 & 40 \\
$\quad$ Shawerma & 20 & 7 & 70 & 3 & 30 \\
$\quad$ Shiesh Tawook & & & & & \\
Full cooked product: & & 7 & 70 & 3 & 30 \\
$\quad$ Shawerma & 20 & 8 & 80 & 2 & 20 \\
$\quad$ Shiesh Tawook & & & & \\
*aximum Residual Limit stipulated by Egyptian Organization for Standardization "EOS" $(2005)$.
\end{tabular}


Table (5): results of putrescine levels ( $\mathrm{mg} \%)$ in the examined samples of chicken meat products $(\mathrm{n}=10)$.

\begin{tabular}{lccccc}
\hline \multirow{2}{*}{ Chicken meat } & Positive samples & & \\
& & & Min & Max & Mean \pm S.E \\
\hline Raw thigh & 7 & 70 & 1.0 & 9.6 & $4.54 \pm 0.32^{\mathrm{NS}}$ \\
Raw breast & 6 & 60 & 1.0 & 7.3 & $4.15 \pm 0.25$ \\
Half cooked Shawerma & 9 & 90 & 1.6 & 20.2 & $11.41 \pm 0.96^{+}$ \\
Half cooked Shiesh Tawook & 7 & 70 & 1.4 & 16.7 & $9.98 \pm 1.08$ \\
Fully cooked Shawerma & 8 & 80 & 1.4 & 15.8 & $8.01 \pm 0.63^{\mathrm{NS}}$ \\
Fully cooked Shiesh Tawook & 7 & 70 & 1.1 & 13.5 & $7.47 \pm 0.50$ \\
NS= Non-significant differences $(P<0.05)$ between raw (thigh \& breast) and between fully cooked (shawerma \& shiesh tawook) \\
$\quad$ + Significant differences $(P<0.05)$ between half cooked (shawerma \& shiesh tawook)
\end{tabular}

Table (6): Acceptability of the examined samples of raw and heat treated chicken meat products based on their levels of putrescine

\begin{tabular}{lccccc}
\hline Chicken Products & $\begin{array}{c}\text { MRL } \\
(\mathrm{mg} \%)^{*}\end{array}$ & \multicolumn{2}{c}{ Accepted samples } & \multicolumn{2}{c}{ Unaccepted samples } \\
No. & $\%$ & No. & $\%$ \\
\hline Raw chicken meat: & 20 & 10 & 100 & 0 & 0 \\
$\quad$ Thigh & & 10 & 100 & 0 & 0 \\
$\quad$ Breast & & & & & \\
$\quad$ Half cooked product: & & 9 & 90 & 1 & 10 \\
$\quad$ Shawerma & 20 & 10 & 100 & 0 & 0 \\
$\quad$ Shiesh Tawook & & & & & \\
$\quad \begin{array}{l}\text { Full cooked product: } \\
\quad \text { Shawerma }\end{array}$ & 20 & 10 & 100 & 0 & 0 \\
$\quad$ Shiesh Tawook & & 10 & 100 & 0 & 0 \\
\hline Maximum Residual Limit stipulated by Egyptian Organization for Standardization "EOS" (2005).
\end{tabular}

\section{DISSUCSION}

Proteolysis, either autolytic or bacterial, may play a significant role in the release of free amino acid from tissue proteins which offer a substrate for decarboxylases reactions forming the biogenic amines (Balamatsia et al., 2007; Shalaby, 1996).

The results of histamine agreed with those reported by Abd-Zahir (2013) $(8.41 \pm 0.33 \mathrm{mg} \%)$ for chicken wing, $(10.75 \pm 0.39 \mathrm{mg} \%)$ for thigh and $(17.28 \pm 0.52 \mathrm{mg} \%)$ for chicken shawerma. Nearly similar results were obtained by El-Wakeel (2012) $(11.25 \pm 0.59 \mathrm{mg} \%)$ for grilled chicken and Ntzimani et al. (2008) $(11.9 \mathrm{mg} / 100 \mathrm{gm})$ in smoked turkey breast fillets. While, higher than Afifi and Amin (2010) (9.61 \pm 1.44$)$ for ready to eat chicken shawerma and also higher than Nassar and Emam (2002) in all heat treated chicken products

The high level of histamine in the examined half cooked and fully cooked shawerma \& sheish tawook samples may be attributed to unfavorable temperature of processing, presence of additives as pepper, tomatoes and other spices, which played an important role in growth and multiplication of such histamine forming microorganisms (Fonberg Broczek and Sawilska - Rautenstrauch, 1995).
These results of cadaverine were higher than those of Abdel-Zahir-Hager (2013) (4.18 \pm 0.11 $\mathrm{mg} \%$ ) for thigh, ( $9.35 \pm 0.11 \mathrm{mg} \%$ ) for shawerma and Nassar and Emam (2002) (3.14 \pm 0.47 , $3.71 \pm 0.57,4.06 \pm 0.85 \mathrm{mg} \%$ ) for chicken frankfurter and luncheon.

Results of putrescine were lower than those of El-Wakeel (2012) (13.08 $\pm 0.89 \mathrm{mg} \%)$ for grilled chicken, higher than those of Afifi and Amin (2010) $(5.69 \pm 0.83 \mathrm{mg} \%)$ for ready to eat shawerma and Eliassen (Eliassen et al., 2002) et al. (2002) (in grilled breast $2 \mathrm{mg} / \mathrm{kg}$ ), and Patsias et al. (2006) (in fried breast $0.7 \mathrm{mg} / \mathrm{kg}$ ).

Cadaverine and putrescine could be indicators for onset of spoilage of poultry, especially since they were detected in the prespoilage stages from colony count $10^{5} \mathrm{cfu} / \mathrm{cm}^{2}$ (Schmitt and Schmidtlorenz, 1992).

The high concentration of putrescine in the examined samples of half cooked and fully cooked chicken shawerma \& shiesh tawook indicated inappropriate treatment, poor hygienic levels of manufacturing process, using raw materials of poor quality (Kalac, 2006) and increased microbial contamination (Krausova et al., 2006; RuizCapillas et al., 2004). 
One direction in cancer therapy research is to limit the intake of dietary putrescine (Cipolla et al., 2007).

From the public health point of view, putrescine persists an important interest because it can react with nitrates to form nitrosamine which have carcinogenic effects on human being (Oliveira et al., 1995).

In general, there were great fluctuations of biogenic amines content among types of products and in the same type of the product. These differences depend on many variables as the composition of microflora, the chemico - physical variables, the hygienic procedure adopted during processing, the availability of precursors, the amount of meat used, types of ingredients added and the quality of the raw material (Silva and Glória, 2002; Suzzi and Gardini, 2003).

In conclusion, the formation of biogenic amines depends on addition of acidic materials to shawerma and sheish tawook as onion juice lowers $\mathrm{pH}$ of the product, so activating the acidic bacteria to form biogenic amines.

\section{REFRENCES}

Abd-Zahir, H. 2013. Chemical aspect of chicken cut-up meat productsM.V.Sc., Benha University.

Afifi, G.S., Amin, R.A., 2010. Correlation between biogenic amines content and the bacterial load of some ready-to-eat chicken products. Alex. Vet. Sci. J. 30, 21-32.

Balamatsia, C.C., Paleologos, E.K., Kontominas, M.G., Savvaidis, I.N., 2006. Correlation between microbial flora, sensory changes and biogenic amines formation in fresh chicken meat stored aerobically or under modified atmosphere packaging at 4 degrees $\mathrm{C}$ : possible role of biogenic amines as spoilage indicators. Anton Leeuw Int J G 89, 9-17.

Balamatsia, C.C., Paleologos, E.K., Kontominas, M.G., Savvaidis, I.N., 2007. Possible role of volatile amines as quality indicating metabolites in modified atmosphere packaged chicken fillets: Correlation with microbiological and sensorial attributes. J. Food Chemistry 104, 1622-1628.

Cipolla, B.G., Havouis, R., Moulinoux, J.P., 2007. Polyamine contents in current foods: a basis for polyamine reduced diet and a study of its long term observance and tolerance in prostate carcinoma patients. Amino Acids 33, 203-212.
Egyptian Organization for Standardization "EOS", 2005. Reports related to No 2019/2005 J. for chicken and turkey meat products Egyption Standards. Ministry of Industry, Egypt.

El-Wakeel, M.E. 2012. Biogenic amines in fast food at hotel levelsM.V.Sc., Benha Univ.

Eliassen, K.A., Reistad, R., Risoen, U., Ronning, H.F., 2002. Dietary polyamines. Food Chemistry 78, 273-280.

Feldman, D., Ganon, J., Haffman, R., Simpson, J., 2003. The solution for data analysis and presentation graphics, 2nd ed. Abacus Lancripts, Inc., Berkeley, USA.

Fonberg - Broczek, M., Sawilska - Rautenstrauch, D., 1995. Level of histamine and tyramine in ripening cheese. Rocz Panstw Zakl Hig 46, 243-246.

Halasz, A., Barath, A., Simonsarkadi, L., Holzapfel, W., 1994. Biogenic-Amines and Their Production by Microorganisms in Food. Trends in Food Science \& Technology 5, 42-49.

Jean, D.C., Caterina, C., Fabiano, T., Marco, A., 2001. Production of biogenic amines in Italian salami "fermented sausage". J. Meat Sci. 67, 607-616.

Kalac, P., 2006. Biologically active polyamines in beef, pork and meat products: A review. Meat Science 73, 1-11.

Kozova, M., Kalac, P., Pelikanova, T., 2009. Changes in the content of biologically active polyamines during beef loin storage and cooking. Meat Sci 81, 607-611.

Krause, I., Bockhardt, A., Neckerman, H., Henle, T., Klostermeyer, H., 1995. Simultaneous determination of amino acids and biogenic amines by reserved phase high-performance liquid chromatography of the dabsyle derivatives. J. Chromatography A. 715, 6779.

Krausova, P., Kalac, P., Krizek, M., Pelikanova, T., 2006. Content of biologically active polyamines in livers of cattle, pigs and chickens after animal slaughter. Meat Sci 73, 640-644.

Nassar, A.M., Emam, W.H., 2002. Biogenic amines in chicken meat products in relation to bacterial load, $\mathrm{pH}$ value and sodium chloride content. Nahrung 46, 197-199.

Ntzimani, A.G., Paleologos, E.K., Savvaidis, I.N., Kontominas, M.G., 2008. Formation of biogenic amines and relation to microbial flora and sensory changes in smoked turkey breast fillets stored under various packaging conditions at 4 degrees C. Food Microbiology 25, 509-517. 
Oliveira, C.P., Gloria, M.B.A., Barbour, J.F., Scanlan, R.A., 1995. Nitrate, Nitrite, and Volatile Nitrosamines in Whey-Containing Food-Products. Journal of Agricultural and Food Chemistry 43, 967-969.

Patsias, A., Chouliara, I., Paleologos, E.K., Savvaidis, I., Kontominas, M.G., 2006. Relation of biogenic amines to microbial and sensory changes of precooked chicken meat stored aerobically and under modified atmosphere packaging at 4 degrees C. European Food Research and Technology 223, 683-689.

Petracci, M., Cavani, C., 2012. Muscle growth and poultry meat quality issues. Nutrients 4,1 12.

Pinho, O., Ferreira, I.M.P.L.V.O., Mendes, E., Oliveira, B.M., Ferreira, M., 2001. Effect of temperature on evolution of free amino acid and biogenic amine contents during storage of Azeitao cheese. Food Chemistry 75, 287291.

Rokka, M., Eerola, S., Smlander, M., Alakomi, H.L., Ahvenainen, R., 2003. Monitoring of the quality of modified atmosphere packaged broiler chicken cuts stored in different temperature conditions B. Biogenic amines as quality-indicating metabolites. J. Food Control 15, 601-607.

Ruiz-Capillas, C., Cofrades, S., Serrano, A., Jimenez-Colmenero, F., 2004. Biogenic amines in restructured beef steaks as affected by added walnuts and cold storage. Journal of Food Protection 67, 607-609.

Schmitt, R.E., Schmidtlorenz, W., 1992. Formation of Ammonia and Amines during Microbial Spoilage of Refrigerated Broilers. Food Science and TechnologyLebensmittel-Wissenschaft \& Technologie 25, 6-10.

Shalaby, A.R., 1996. Significance of biogenic amines to food safety and human health. Food Research International 29, 675-690.

Silva, C.M.G., Glória, M.B.A., 2002. Bioactive amines in chicken breast and thigh after slaughter and during storage at $4 \pm 1 \mathrm{oC}$ and in chicken - based meat products. . J. Food Chem. 78, 241-248.

Suzzi, G., Gardini, F., 2003. Biogenic amines in dry fermented sausages: a review. Int J Food Microbiol 88, 41-54. 